\title{
New Identification Key for some Acaridides (Acaridida) from Upper Egypt, with Description of a New Acaridae Species
}

\author{
S. A. Eraky* and M. A. Osman ** \\ "Plant Protection Dept., Faculty of Agric., Assiut Univ., Assiut 71516 Egypt. E.mail: seraky53@ yahoo.com \\ *Agric. Zoology Dept., Faculty of Agric., Mansoura Univ., Mansoura Egypt.E. Mail: mesoma20@mans.edu.eg
}

\begin{abstract}
The study herein presents brief characterizations and a new identification key for some Acaridides (43 species) collected from different habitats in upper Egypt during 1993 to 2003 in addition to a new species. The present key of the Acaridides hypopi is a blending of both keys illustrated by Eraky, 1997 (for 16 histiostomatid species pertaining to 6 genera) and Eraky, 2000 (for 26 histiostomatid and acaridid species belonging to 12 genera). While, Eraky (1990) erected an identification key for all histiostomatid genera, the present work is a continuity of the collecting activity of the first author. Samples were collected from manure and dunghills (Assiut and Sohag Governorates), planted onion and garlic, potato tubers, pomegranate and date fruits, uprooted banana suckers and rodent burrows (Assiut Governorate) ; nests of termites (Aswan, Qena and New Valley Governorates) and skin of dead animals (El-Minia governorate). The identification key is simple and easy to understand and the diagnosis is in most cases based on genera and species. A new mite species, extracted from nests of termites in Qena Governorate, is described and illustrated.
\end{abstract}

KeY WoRDS: Acari, Acaridida, Acaridides, Identification, Egypt.

\section{INTRODUCTION}

Mites of Acaridida are among the most successful arthropods to exploit spatial and temporally restricted habitats. Dispersal between habitat patches is affected by phoretic association between the specialized deutonymphs of the Acaridida mites and the host which may be either another arthropod or a vertebrate (OC'onnor, 1982, and Houck and OC'onnor, 1991). About half of the known species of the Acaridida group consists of the permanent parasites of insects, birds, mammals, including species of considerable medical and veterinary importance such as scabies and housedust allergy mites. Knowledge of the morphology and the systematic of the group is still in a relatively early stage of development, most non-parasitic species have been described from either the adults or the dispersing deutonymphs, but not both. With the exception of some group of mammalian ectoparasites, relatively few species have been described from any group of Acaridida mites in most areas of the world, especially in Egypt. The only studies of Acaridida mites which attempted to describe an entire local fauna (Germany) were the companion studies of the family: Histiostomatidae (= Anoetidae Oudemans,19o4) 'by Scheucher (1959) and Family: Tyroglyphidae by Turk and Turk (1959) and the systematic studies of the Acaridida fauna of North America by OC'onner (1989; 1990 and 1991) and OC'onnor and Houck (1989). Many species pertaining to this group were recorded in Upper Egypt by Eraky (1993, 1994 a \& b, 1997, 1998, 1999a,b \& c and 2000 a \& b) and Eraky and Shoker (1993 and 1994). On the other side, an accumulated knowledge concerning the Acaridides fauna in Egypt is extremely poor as compared with the other group of mites, many points concerning to this group are questionable. However, several taxa were found to be new and several morphological characteristics were described. Superchort Acaridides contains the species of economic importance, utilizes a wide range of food including grain, fishmeal and substances containing sugars (e.g. dried fruits) but the large number of acaridid species associated with these materials and relatively few can be considered as an important pests (Hughes, 1976). Although the Acaridida mite is comparatively small as compared with the other groups of mites, it is nevertheless one of the most successful group of animal on earth, through their unique methods of dispersal, omnivorous food habits and phenomenal rate of reproduction. This group includes the economically important families, of which some cause mange and scabies in domestic animals, a number of families include parasites and commensals of mammals and birds, and those associated with stored products. In addition to infesting food, certain species also live in human habitats where they are found in damp situations favoring the growth of fungi upon which they feed. Members of one family, commonly referred to as house dust mites, are of considerable medical importance in being the causative agents of a topic asthma and rhinitis; the allergens being present in their fecal pallets. The majority of species are living as saprophytic and fungivores in soil, litter, debris and organic manure. Others can be found on different economical plants, causing injury to plant directly by feeding, or by transmitting various disease agents (Zakhvatkin, 1941; Baker and 
Wharton, 1952; Scheucher, 1959; Hughes \& Jackson, 1958 and Hughes, 1961 \& 1976). Hypopus in this group is a succeeding stage both in dispersal and behavior, highly resistant to environmental stress. Some are adapted for dispersal by phoresy; in most cases phoretic on insects by having attachment organs in the form of sucker-plate (Zakhvatkin, 1941; Griffiths, 1977; Houck \& OConnor 1991; OConnor, 1994 and Kettle, 1995). Study on the Acaridida has received the attention of several authors (viz.,Samsinak, 1957, 1960,1962 a \& b,1966 and 1972 in Czeck Republic; Griffits, 1960, 1964, 1966 and 1967 in England; Mahunka, 1961 a \& b, 1962 a \& b, 1963 a \& b, 1964,1967,1968, 1969 a \& b, 1972,1973 a, b, c, 1974 a \& b, 1975 a \& b, 1976,1977, 1978 a, b, c \& d, 1979,1981, and 1982 a $\& \mathrm{~b}$ and Mahunka and Eraky 1987 in Hungary; Woodring, 1963; 1969 \& 1973 and OC'onnor, 1982, 1984a \& b, 1989, 1990, 1991, 1993 and 1997 in America; Fain, 1967 to 1984 in Belgium; Eraky, 1993 to 2000 , Eraky and Shoker, 1993 and 1994 and Abdel-Sater and Eraky, 2002 in upper Egypt and others).

\section{Description of the new species Acotyledon ahmadi sp.n. (Hypopus)}

Measurements: Length : 240-257 $\mu \mathrm{m} \&$ Width: 136-175 $\mu \mathrm{m}$.

Dorsum (Fig.1). Body approximately elongate, ovoid in its shape, propodosoma (Fig.3) comparatively triangular in its outline, its surface smooth. Both pairs of dorsal setae of propodosoma long and thick; inner one longer and standing somewhat anteriorly to the outer pair. Setae (Sex) long, robust and curved and originating anterolaterally to scapular setae (Sci). Dorsosejugal region ornamented with transverse ines. Entire notogastral surface similarly smooth; the posterior part ornamented with scarce granulae. Notogastral setae long and thick.

Ventrum (Fig.2). Infracapitulum of gnathosoma (Fig.3) long; palpi separated off; solenidia long and thick; infracapitular setae minute hardly visible. All apodemes well-chitinized; ap.sa ending free with Y-shape, thus epimere I open, ap.II long, fused with sejugal apodemes, epimere II closed. Inertmediate sternal apodeme missing and posterior sternal apodeme short ending free, far from primordial of genital opening; ap.III and ap.IV of posterior sternal plate long, forming a close net work. Epimere I with alveoli; epimere III without any sculpture and epimere IV with large suction disks in addition to a pair of simple setae standing beside primordial genital opening.

Adhering plate (Fig.4). Adhering plate relatively large, removed from the body end. Disk D of adhering plate well-developed, while disks Ds reduced; D1 and D2 disks approximately large, on this latter the two inner rings removed from each other.

Legs (Figs.6-9). Tarsi of legs I-IV with 1-2 lanceolate setae each. Solenidia co i of tarsi of legs I and II long and thick. Solenidia (pi much longer than entire tarsi of both legs. Solenidia 0)3 short and thin . Tibial solenidia on legs I long and thick, those on legs II shorter and thinner.Legs III and IV with several simple setae each.

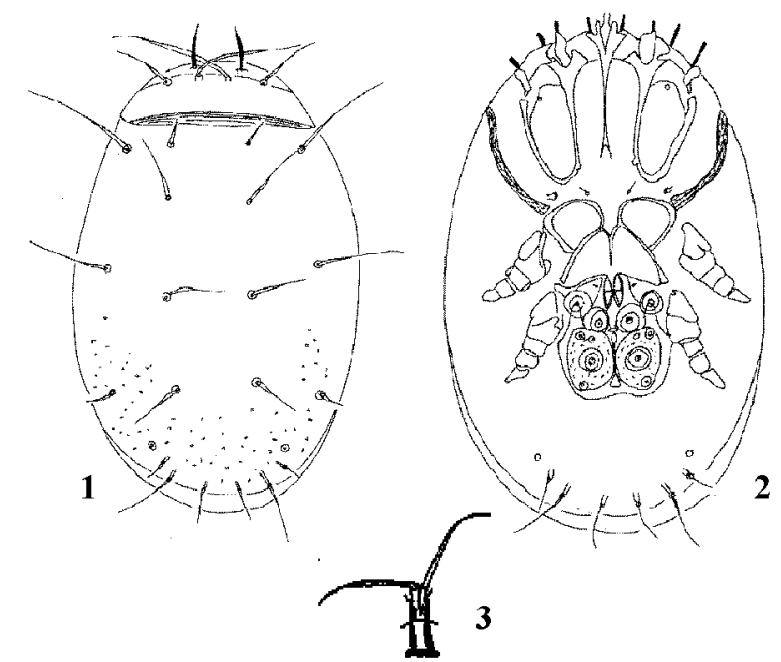

Figs. (1-3): Acotyledon ahmadi sp.n. (Deutonymph) 1: Dorsum, 2: Ventrum, 3: Gnathosoma.

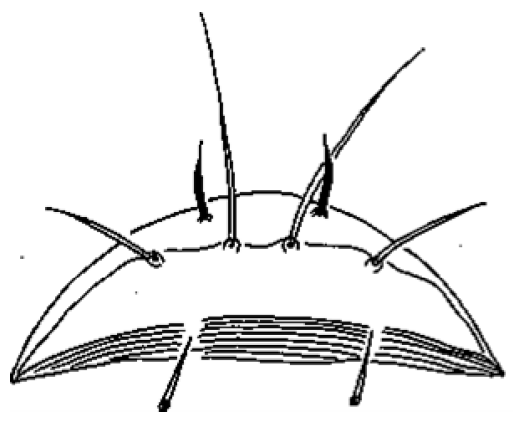

4

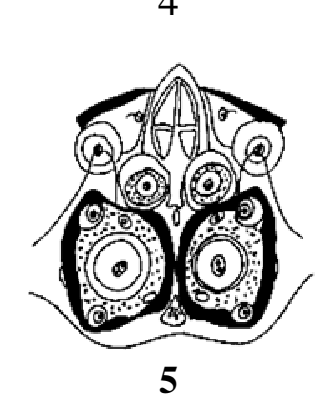

Figs.(4-5): Acotyledon ahmadi sp.n. (Deutonymph) 4: Propodosoma, 5: Adhering plate 


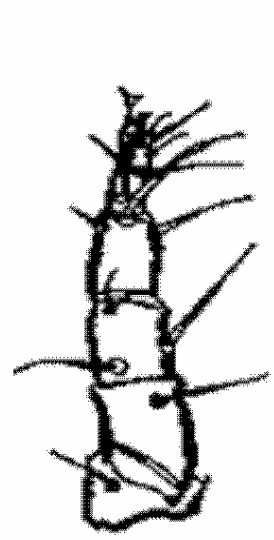

6

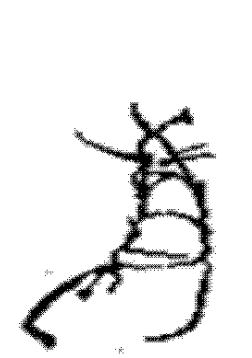

8

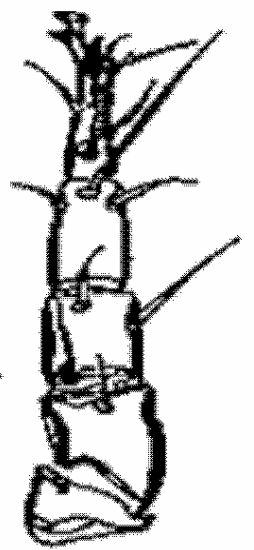

7

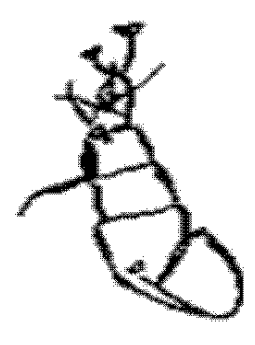

9

Figs. (6-9): Acotyledon ahmadi sp.n. (Deutonymph) 6: Leg n I; 7: Leg II; 8: Leg III; 9: Leg IV.

Material examined: A holotype and 10 paratypes extracted from nests of termites, Qena, Egypt, June 2002. The holotype and 7 paratypes deposited in Plant Protection Department, Faculty of Agriculture, Assiut University, Assiut Egypt; 3 paratypes deposited in the Arachnoidea Collection of the Hungarian Natural History Museum, Budapest.

Remarks: The new species stands very near to Acotyledon lamiai Eraky, 1998 (Fig. 10-16) collected from the nests of termites El-Kharga Oasis, New Valley, Egypt and may be distinguished from it by the following characters:

lamiai Eraky, 1998

- Dorsosejugal region smooth, without any sculpture, infracapitulum of gnathosoma short, hardly longer than wide.

- Posterior apodeme epimeres III and IV open. ahmadi sp.n.

$\begin{array}{lr}\text { - Dorsosejugal } & \text { region } \\ \text { ornamented } & \text { with } \\ \text { transversal } & \text { lines, } \\ \text { infracapitulum } & \text { of } \\ \text { gnathosoma } & \text { long, } \\ \text { longer than wide. }\end{array}$

- Posterior sternal apodeme present, short ending free, .epimere III closed and epimere IV open.

- Epimere ap. sa ending free, just in front of sejugal apodemes.

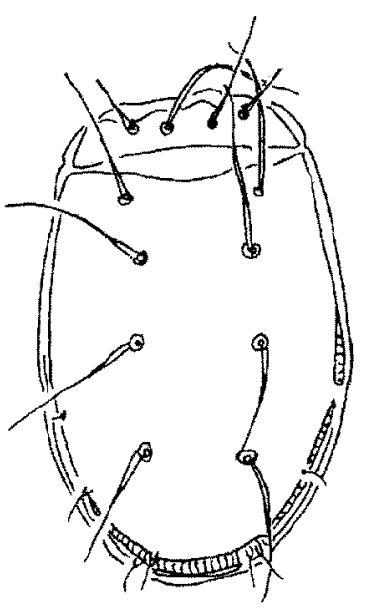

10

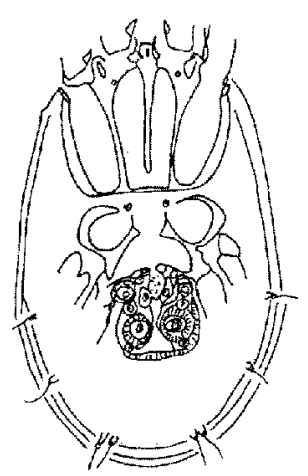

11
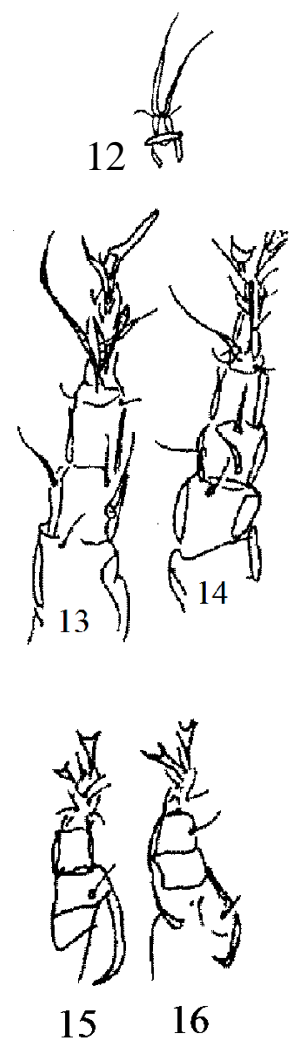

Figs.10-16. Acotyledon lamiai Eraky; 1998 (Deutonymph) 10: Dorsum; 11:Ventrum, 12: Gnathosoma, 13: Leg I; 14: Leg II; 15: Leg III; 16: Leg IV. 
Table (1): Distribution of some Acaridides in Upper Egypt.

\begin{tabular}{|c|c|c|c|}
\hline No. & Mite species & Habitat & Area of study \\
\hline \multicolumn{4}{|c|}{ Family: Acaridae Ewing and Nesbitt, 1942} \\
\hline 1 & Acarus solimani Eraky, 1999c & Nests of termites & Aswan \\
\hline 2 & Acotyledon manuri Eraky, 1999b & Manure of animals & Assiut \\
\hline 3 & Acotyledon nerminkai Eraky, 1999b & Manure of animals & Assiut \\
\hline 4 & Acotyledon longsetoses Eraky, 1999a & Nests of termites & Aswan \\
\hline 5 & Acotyledon lamiai Eraky, 1998 & Nests of termites & N. Valley \\
\hline 6 & Acotyledon ahmadi sp.n. & Nests of termites & Qena \\
\hline 7 & Caloglyphus csibbii Eraky, 1999b & Potato tubers & Assiut \\
\hline 8 & Caloglyphus ornatus Eraky, 2000a & Nests of termites & Aswan \\
\hline 9 & Caloglyphus arafati Eraky, 2000a & Manure of animals & Assiut \\
\hline 10 & Calvolia solimani Eraky, 1999a & Nests of termites & Aswan \\
\hline 11 & Calvolia zaheri Eraky, 1998 & Nests of termites & N. Valley \\
\hline 12 & Cosmoglyphus barbisetus Eraky, 1999c & Nests of termites & Aswan \\
\hline 13 & Forcellinia egyptiaca Eraky, 1998 & Nests of termites & N. Valley \\
\hline 14 & Forcellinia mahunkai Eraky, 1999d & Manure of animals & Sohag \\
\hline 15 & Froriepia negmi Eraky, 1999a & Nests of termites & Aswan \\
\hline 16 & Mahunkaglyphus solimani Eraky, 1998 & Nests of termites & N. Valley \\
\hline 17 & Mahunkallinia serratus Eraky, 1999a & Nests of termites & Aswan \\
\hline \multicolumn{4}{|c|}{ Family: Histiostomatidae (=Anoetidae Oudemans, 1904) } \\
\hline 18 & Anoetostoma nerminka Eraky and Shoker, $1993 \mathrm{~b}$ & Rodent burrows & Assiut \\
\hline 19 & Copronomoia mahunkai Eraky, 1999b & Manure of animals & Assiut \\
\hline 20 & Copronomoia sphaerocerae (Vitzthum, 1922) & Manure of animals & Assiut \\
\hline 21 & Glyphanoetus processum Eraky, 1994a & Planted garlic & Assiut \\
\hline 22 & Glyphanoetus mahunkai Eraky, 1994a & Manure of animals & Assiut \\
\hline 23 & Glyphanoetus onioni Eraky, 1999c & Root of planted onion & Assiut \\
\hline 24 & Histiostoma allii Eraky, 2000b & Manure of animals & Sohag \\
\hline 25 & Histiostoma camphori Eraky, 1999c & Nests of termites & Aswan \\
\hline 26 & Histiostoma farghali Eraky, 2000b & Manure of animals & Sohag \\
\hline 27 & Histiostoma mannai Eraky, $1999 \mathrm{~b}$ & Nests of termites & Aswan \\
\hline 28 & Histiostoma manuri Eraky, 2000b & Manure of animals & Sohag \\
\hline 29 & Histiostoma negmi Eraky, 2000b & Manure of animals & Sohag \\
\hline 30 & Histiostoma sammari Eraky, 1999c & Nests of termites & Aswan \\
\hline 31 & Histiostoma tinydorsalis Eraky, 1999 & Manure of animals & Assiut \\
\hline 32 & Histiostoma darwishii Eraky, 1994a & Manure of animals & Assiut \\
\hline 33 & Histiostoma onioni Eraky and Shoker, 1994 & Stored onion & Assiut \\
\hline 34 & Histiostoma sarrai Eraky and Shoker, 1994 & Stored onion & Assiut \\
\hline 35 & Histiostoma nasseri Eraky, 1994b & Pomegranate and date & Assiut \\
\hline 36 & Histiostoma rizkii Eraky, 1994b & Pomegranate and date & Assiut \\
\hline 37 & Histiostoma egyptiacum Eraky and Shoker, 1993a & Uprooted banana suckers & Assiut \\
\hline 38 & Histiostoma pickaxei Eraky and Shoker, 1993b & Skin of dead animals & El-Minia \\
\hline 39 & Histiostoma bananai Eraky and Shoker, 1993a & Uprooted banana suckers & Assiut \\
\hline 40 & Histiostoma solimani Eraky, 1997 & Manure of animals & Assiut \\
\hline 41 & Histiostoma zaheri Eraky, 1997 & Manure of animals & Assiut \\
\hline 42 & Hormosianoetus mahunkai Eraky and Shoker, 1993a & Uprooted banana suckers & Assiut \\
\hline 43 & Myianoetus lili Eraky, 1993 & Manure of animals & Assiut \\
\hline
\end{tabular}

All types established herein are deposited in the Acari Collection of Plant Protection Department, Faculty of Agriculture, Assiut University, Egypt and in the Arachnoidea Collection of the Hungarian Natural History Museum, Budapest, Hungary. 


\section{Key of 43 Acaridides species Collected from different habitats in Upper Egypt}

The present study includes an identification key for 43 Acaridides mite species (Table 1) belonging to 2 families and 15 genera, based on the morphological characters of the hypopial stage.

(Drawings of all species are presented in Eraky 1994 a\&b, 97, 98, 99 a, b\&c, and 2000 a \& b)

1 (67) All legs long and tapering, the two hind pairs of legs being directed forward......Family: Histiostomatidae

2 (50) Epimeres I and III with well-developed normal suckers or cups; sensory setae of leg I normal developed, shorter than entire tarsus.

3 (55) All legs with well-developed claws; dorsosejugal region with sculpture consists of transversal lines, ribs or striations.

4(61) No oval field on the anterolateral region of the notogaster, surface of notogaster smooth, without any sculpture.

5 (58) Suctorial plate normal developed (e.g. two pairs of movable, two pairs of immovable suckers and five other structures: ring or cups); epimeres I and III with normal suckers or discs.

6 (64) Claws on all legs normal-developed; discs D and Ds of adhering plate of normal size and shape.

7 (65) Surface of notogaster smooth; legs IV with well-developed claws.

8 (10) Apodemes III and sejugal ones clearly differentiated; D and Ds discs of adhering plate well observable

9 (12) Dorsal setae very long and thick, except the marginal ones, inner scapular setae also long, approximately at the same length of the outer ones.

10(8) Apodemes III and sejugal apodemes unseparated; Ds discs of adhering plate not or scarcely distinguishable

11(13) Dorsosejugal region missing, only a stripy band present as a dorsosejugal suture; infracapitulum of gnathosoma wide medially.

Histiosotma alii Eraky, 2000b

12 (9) All dorsal setae very short and thin; inner pair of scapular setae shorter than the outer one

13 (11) Dorososejugal region present, ornamented with transversal lines; infracapitulum of gnathosoma normal and oblong.

14 (15) Apodomes III and sejugal ones undifferentiated; adhering setae of tarsi of legs I and II large and spoonshaped

Histiostoma farghali Eraky, 2000b

15 (14) Apodermes III and sejugal apodomes unseparated, latters have a small lateral arch, adhering setae of tarsus I long and falcate-shaped; that of leg II long and setiform.

16(18) Dorsosejugal region present, ornamented with lineolae; notogastral setae approximately long, but thin, the marginal ones much thinner and shorter.

17(19) Inner pair of prodorsal setae much longer than the outer one; entire surface of epimeres III and IV ornamented with punctulae

Histiostoma manuri Eraky, 2000b

18(16) Dorsosejugal region present, ornamented with rough sculpture; notogastral setae very short and thin.

19(17) Inner pair of prodorsal setae short, at the same length of the outer one, entire surface of epimeres III and IV smooth, without any sculpture.

20(22) Apodemes III and sejugal apodemes undifferentiated, arc of latter bulging forward to a great extent, forming a large bay in the middle; propodosoma normal-developed, approximately wide.

21(23) Adhering setae of tarsus I short; those of leg II longer, former one spoon-shaped, latter one setiform; legs III and IV with setiform terminal setae each; gnathosoma normal and oblong

Histiostoma mannai Eraky, 1999b

22(20) Apodoemes III and sejugal apodemes delimitated by faint lines, propodosoma very small and narrow.

23(21) Adhering setae of tarsus I large and spoon-shaped, those of leg II large and phylliform. Legs III and IV with thin and long ones; gnathosoma normal and wide medially.

24(27) Dorsosejugal region approximately wide, ornamented with striation; inner pair of prodorsal setae short, slightly longer than the outer pair and standing a little infront of them.

25(28) Dorsal setae scarce or missing; surface of propodosoma smooth. 
26(29) Solenidia col and cpl of tarsi I and II normal-developed; apodemes III touching each other medially Histiostoma tinydorsalis Eraky, 1999c

27(24) Dorsosejugal region normal, ornamented with rough sculpture; inner pair of prodorosal setae at the same length of the outer one and standing far anteriorly of them.

28(25) Dorsal setae well observable yet short; anterior part of propodosoma ornamented with lineolate.

29(26) Solenidia $\omega 1$ and $\varphi$ pi of tarsi I and II large and clavate; apodemes III free medially; sejugal apodemes represented only fragmentally

Histiostoma camphori Eraky, 1999c

30(51) Dorsosejugal region present ornamented with striation; both pairs of scapular setae short and thin, originating far from each other, behind the lateral margin of the propodosoma.

31(56) Apodemes III not touching each other medially and have a small lateral arch; sejugal apodemes missing; intermediate sternal apodemes long Histiostoma sammari Eraky, 1999c

32(34) Apodemes III and sejugal apodemes clearly separated; the latter fused with posterior sternal apodema; propodosomatic surface smooth; hysterosomatic surface ornamented with granules.

33(35) Dorsosejugal region present, ornamented with short rugae; epimeres I with small suction cups, epimeres III and IV with alveoli

Histiostoma darwishii Eraky, 1994a

34(32) Apodemes III and sejugal ones clearly differentiated, both free in the middle, not fused with posterior sternal apodema, surface of propodosoma smooth, that of hysterosoma ornamented with scarce granules Histiostoma onioni Eraky \& Shoker, 1994

35(33) Dorsosejugal region present, ornamented with transverse lines; epimeres I, III and IV with well-developed normal suckers or discs.

36(37) Apodemes III and the straight sejugal apodemes hardly separated; surfaces of propodosoma and hysterosoma smooth without any sculpture..

Histiostoma sarrai Eraky \& Shoker, 1994

37(36) Apodemes III and the straight sejugal ones clearly separated; surface of hysterosoma smooth; propodosomatic surface with increasingly small foveolae towards the middle and with well-developed two lines standing behind the lateral margin of propodosoma.

38(40) Suctorial plate large and pear-shaped occupying entire body surface behind and partly between legs IV; inner propodosomatic setae much longer than the outer ones.............. Histiostoma nasseri Eraky, 1994b

39(41) Apodemes III and sejugal apodemes not differentiated; latter slightly arched medially with large arch standing anteriolaterally; surface of hysterosoma smooth; propodosoma with a line decurrent parallel with the body margin

Histiostoma rizkii Eraky, 1994b

40(38) Suctorial plate normal in shape and size, standing not far from the posterior body margin; inner scapular setae at the same length of the outer ones and originating infront of them.

41(39) Apodemes III and the straight sejugal apodemes well-separated; the latter slightly arched medially, and laterally straight with three teeth on each side; propodosomatic surface with scattered granules; hysterosomatic surface covered with elongated alveoli laterally and maculae medially

Histiostoma egyptiacum Eraky and Shoker, 1993a

42(44) Surface of propodosoma ornamented with transverse lines laterally and short rugae medially; dorsosejugal region and surface of hysterosoma covered with regular and longitudinal lines decurrent parallel along the surface; propodosomatic setae short, at the same length, originating along a common line up and parallel the dorsosejugal suture.

43(45) Apodemes I originating normally; no triangular area below gnathosoma; epimeres I with well-developed lines decurrent from apodemes I to the middle of apodemes II

Histiostoma bananai Eraky and Shoker, 1993a

44(42) Dorsal surface smooth; dorsosejugal region ornamented with transverse lines; propodosomatic setae standing far from dorsosejugal suture.

45(43) Apodemes 1 originating far from each other, with wide triangular area below gnathosoma; no lines decurrent between apodemes 1 and II, hence all epimeres open.

Histiostoma pickaxei Eraky and Shoker, 1993b

46(48) Apodemes II long, fused posteriorly with sejugal ones; latters closed medially with a comparatively large lateral arch; apodemes III free medially; no sculpture between coxal fields IV.

47(49) Dorsosejugal region present ornamented with short rugae; solenidia (pi of tarsus I, much longer than solenidia $\omega 1$, the famulus missing......

Histiostoma zaheri Eraky, 1997 
48(46) Apodemes II short, ending free, far from sejugal ones; apodemes III and sejugual ones well-separated, both closed medially; a genital slit surrounded with a punctulate area between coxal fields IV.

49(47) Dorsosejugal region present, ornamented with transverse lines; solenidia (pi of tarsus I, slightly longer than solenidia Omega-1, the famulus long and thin Histiostoma solimani Eraky, 1997

50(2) Epimeres I without normal suckers or cups; epimeres III with normal suction cups; sensory setae of legs I much longer than entire tarsus.

51(30) Dorsosejugal region present ornamented with transverse lines; both pairs of prodorsal setae approximately long, inner pair shorter and thicker than the outer one.

52(68) All legs with normal claws; hysterosomatic and propodosomatic surfaces ornamented with foveolae Glyphanoetus onioni Eraky, 1999c

53(54) The posterior four pairs of hysterosomatic setae originating on processes; propodosoma with two incomplete lines standing behind the marginal apex.

Glyphanoetus processum Eraky, 1994a

54(53) The posterior four pairs of hysterosomatic setae originating normally; propodosoma with only incomplete line standing behind the anterior margin of the body Glyphanoetus mahunkai Eraky, 1994a

55(3) All legs with normal-developed claws, except legs IV clawless; dorsosejugal region ornamented with transversal lines.

56(31) Apodemes III fused medially; intermediate sternal apodeme short.

57(59) Dorsosejugal region ornamented with transversal lines; surface of propodosoma with well discernible definite line decurrent approximately parallel with the body margin; hysterosomatic surface ornamented with heavy longitudinal lines regular along the surface.

Hornwsianoetus mahunkai Eraky and Shoker, 1993a

58(5) Suctorial plate with two pairs of conoids; epimeres I and III with alveoli

59(57) Dorsosejugal region present, without any sculpture; propodosomatic and histerosomatic surfaces ornamented with extremely large granulae, larger on propodosoma.

Anoetostoma nerminka Eraky and Shoker, 1993b

60(66) All legs with normal-developed claws, except legs IV clawless; disks D2 of adhering plate very large.

61(4) Notogaster with one pair of oval field standing antero-laterally; surface of hysterosoma ornamented with rough faveolae and or punctulae.

62(63) Hysterosomatic setae very short and simple, hardly observable; surface of propodosoma smooth.

Copronomoia mahunkai Eraky, 1999b

63(62) Hysterosomatic setae scarce or missing; surface of propodosoma with short rugae.

Copronomoia sphaerocerae (Vitzthum, 1922)

64(6) Legs I-III with divided claws each; one pair of large suckers and one pair of much smaller ones existed on suctorial plate.

65(7) Surface of notogaster with sculpture; legs IV clawless

Myianoetus lili Eraky, 1993

66(60) All legs with normal-developed claws each, adhering plate of normal size and shape.

67(1) All legs short and stout, the two hind pairs of legs being directed backward

Family: Acaridae

68(52) All legs with well-developed claws, dorsal surface smooth, without any sculpture

69(87) Dorsosejugal region approximately wide, suctorial plate small removed from the posterior body margin by a distance exceeding its length.

70(88) Propodosoma narrow, approximately sinuous anteriorly, surface of propodosoma smooth.

71(82) Tarsi of legs III and IV long and thin, normally forming a right angle with the rest of the leg, infracapitulum of gnathosoma normal, longer than wide, its surface smooth.

72(75) Tarsi of legs I to IV with 2 spoon-shaped setae each, infracapitulum of gnathosoma short, hardly longer than wide.

73(77) Dorsal setae very long and thick, except the marginal ones, inner pair of prodorsal setae much longer than the outer one Acotyledon ahmadi sp.n.

74(76) Epimeres I and III with alveoli, epimeres IV with normal disks, anterior and posterior sternal plates standing not far from each other Acotyledon lamiai Eraky, 1998 
75(72) Tarsi of legs I to IV with 3 large calyciform setae each, infracapitulum ofgnathosoma long, much longer than wide.

76(45) No any structure on epimeres I, setae on epimeres III and normal disks on epimeres IV, anterior and posterior plates standing far from each other by a long distance ...... Acotyledon longsetoses Eraky, 1999a

77(73) Dorsal setae short and simple, inner scapular setae much shorter than the outer one.

78(80) Infracapitulum of gnathosoma approximately pear-shaped, palpi well-differentiated, epimeral surfaces ornamented with punctulae.

79(81) Intermediate and posterior stemal apodemes missing, suctorial plate normal-developed, all D and Ds disks present ........................................................................ Acotyledon manuri Eraky, 1999b

80(78) Infracapitulum of gnathosoma oblong, palpi hardly differentiated, epimeral surface ornamented with foveolae.

81(79) Posterior sternal apodeme represented only by a very short line; intermediate sternal apodeme missing; Ds2 disks of suctorial plate also missing ....

Acotyledon nerminka Eraky, 1999b

82(71) Tarsi of legs III and IV short and stout; infracapitulum of gnathosoma piriform, surface ornamented with punctulae.

83(89) Tibiae and genoa I and II with very large spines; legs III and IV with several lanceolate setae each.

84(90) Hysterosomatic setae long and thick; each with two lateral branches; the marginal setae very short and simple; scapular setae thick; inner pair originating near each other, almost on rostral apex.

85(95) All apodemes short, thus all epimeres open; dorsosejugal region ornamented with foveolae.

86(96) Inner pair of prodorsal setae shorter than the outer pair; propodosomal margin deeply and arcuately excised Cosmoglyphus barbisetus Eraky, 1999c

87(69) Dorsosejugal region approximately narrow; suctorial plate large, situated not far from the posterior body margin.

88(70) Propodosoma wide, nearly triangular in its outline, and surface with sculpture.

89(83) Tibiae and genoa I and II with small spiniform setae each, legs III and IV with or without one lanceolate setae each.

90(84) Hysterosomatic setae approximately short and thin; scapular setae also thin, inner pair originating far from each other at the middle of propodosoma.

91(94) Body ovoid, anteriorly and posteriorly rounded; surface of propodosoma ornamented with short rugae laterally and punctulae medially.

92(93) One posterior sternal plate, intermediate and posterior sternal apodemes missing; legs I - IV with 1-2 lanceolate setae each

Caloglyphus csibbii Earky, 1999b

93(92) One posterior sternal plate, intermediate sternal apodeme fused with apodemes IV; the posterior one missing. Legs I and II with 1-2, legs III and IV without lanceolate setae.

Caloglyphus arafati Eraky, 2000a

94(91) Body very long, nearly equally rounded anteriorly and posteriorly; propodosoma ornamented with foveolae in its anterior part, its posterior part membranous Caloglyphus ornatus Eraky, 2000a

95(85) All apodemes long, thus all epimeres open, entire surface of epimeres ornamented with punctulae.

96(86) Inner pair of prodorsal setae at the same length of the outer one, propodosoma anteriorly rounded.

97(100) Dorsal setae very short and simple; entire surfaces of all epimeres ornamented with punctulae.

98(99) Dorsosejugal region ornamented with heavy punctulae; infracapitulum of gnathosoma small and rounded. Forcellinia egyptiaca Eraky, 1998

99(98) Dorsosejugal region without any sculpture, infracapitulum of gnathosoma small and trapezoid. Forcellinia mahunkai Eraky, 1999c

100(97) Dorsal setae very short and scarce, entire surfaces of all epimeres smooth.

101(106) Dorsosejugal region wide, ornamented with sculpture consisting of transversal lines; scapular setae short and simple; inner pair much shorter.

102(104) Propodosomal margin convexity rounded, laterally with a denticulate body margin, infracapitulum of gnathosoma wide, approximately trapezoid. Mahunkahinia serratus Eraky, 1999a 
103(107) Epimere I with a minute; epimere III with a very small suction disks; epimeres IV with a pair of setae near primordial of genital opening; tarsi I and II with large, straight claws; legs III and IV with falcate ones.

104(102) Propodosomal margin rounded; gnathosoma developed as a convexity lobular projection, bears only two pairs of setae, inner one very small.

105(108) All apodemes short; ending free in a granulate halo in the middle of the entire body surface; legs I and II with large lanceolate setae each, absent on legs III and IV.

106(101) Dorsosejugal region narrow, ornamented with scarce punctulae, outer pair of scapular setae long and thick, much longer than the inner one. Mahunkaglyphus solimani Eraky, 1998

107(103) Epimeres I, III and IV without any sculpture; legs I and II with normal claws each; legs III and IV with very thin ones.

108(105) Apodemes of anterior sternal plate short, terminating free; no granulate halo present; all apodemes on posterior sternal plate missing; legs I to IV without lanceolate setae, only thin and simple setae present.

109(113) Dorsosejugal region present only as a band; prodorsal setae comparatively long, both pairs at the same length.

110(114) Gnathosoma approximately rounded, bears only a pair of thin and short setae; suctorial plate large, standing close to the posterior margin of the body. Acarus solimani Eraky, 1999c

111(116) Leg I with very long setiform and feebly bent claw; leg II with bottle-shaped one; legs III and IV with long and thick ones each; all apodemes long; epimeres I, II and III closed, posterior sternal apodeme reduced; epimeres IV open.

112(117) Epimeres I, III and IV with normal suction disks each; propodosoma narrow encircling hysterosoma like a narrow strip.

113(109) Dorsosejugal region normal, but narrow, without any sculpture; propodosomal setae reduced.

114(110) Gnathosoma modified, long with thickened base; suctorial plate normal-developed, originating not far from the posterior body margin. Froriepia negmi Eraky, 1999a

115(122) All legs with normal claws, except leg IV clawless; dorsal surface with heavy sculpture.

116(111) Legs I to III with very short claws each; leg IV clawless; apodemes of anterior sternal plate short, ending free, on posterior sternal plate, all apodemes long.

117(112) Epimeres I and III with or without alveoli, epimeres IV with small suction disks; propodosoma enlarged anteriorly, nearly triangular, longer than the half length of hysterosoma.

118(120) Dorsal side ornamented with longitudinal, arcuate and irregular lines; dorsosejugal region smooth, without any sculpture.

119(121) Epimeres I and III without any structure; epimeres IV with normal suction disks and a pair of setae; ap. IV standing far from ap. sp; the later short, not reaching primordial of genital opening.

Calvolia zaheri Eraky, 1998

120(118) Dorsal surface ornamented with punctulae and longitudinal and arcuate lines; propodosoma with punctulae and transverse lines medially; dorsosejugal region ornamented with heavy transversal lines.

121(119) Epimeres I with alveoli; epimeres III without any structure; epimeres IV with a pair of long setae adjacent primordial of genital opening.

Calvolia solimani Eraky, 1999a 


\section{REFERENCES}

Abdel-Sater, M.. A. and Eraky, S. A. 2002. Bulbs mycoflora and their relation with three stored product mites. Mycopathologia. 153: 33-39.

Baker, E.W. and Wharton, G.W. 1952. An introduction to Acarology. The Macmillan Company, New York.465 PP.

Eraky, S.A. 1990. Taxonomy and ecology of some Acarida mites. Ph.D. Thesis, Hungarian Academy of Science, Budapest, Hungary. 113 pp.

Eraky, S.A. 1993. Myianoetus lili sp. n. (Acari : Anoetidae) educed from manure, Assiut, upper Egypt. Folia ent. hung., $54: 47-49$.

Eraky, S.A. 1994a. Three new anoetid mites extracted from animal excrement and from garlic (Acarina : Anoetidae). Folia ent. hung., 55 : 217223.

Eraky, S.A. 1994b. Two new hypopi of Histiostoma Kramer, 1876 (Acari : Astigmata) recovered from pomegranate and date fruits. Assiut J. of Agric. Sci., 25 (2) : 157-162.

Eraky, S.A. 1997. A key to new and old histiostomatid deutonymphs recorded in Assiut area with a descriptions of two new species (Acari : Histiostomatidae). Assiut J. of Agric. Sci., 28 (1): 99-116.

Eraky, S.A. 1998. Mahunkaglyphus solimani gen. and sp. n. and three new species (Acari : Astigmata) described from termite nests, western desert, Egypt. Folia ent. hung., 59 : 241-250.

Eraky, S.A. 1999a. A new genus and three new species of mites (Acari: Acaridida) phoretic on termites infesting the camphor trees in Aswan, Egypt. Annals hist.-nat. Mus.natn. hung., 91: 209-217.

Eraky, S.A. 1999b. Five new hypopial nymphs (Acari: Acaridae and Histiostomatidae) described from different habitats. Folia ent. hung., 60: 45-56.

Eraky, S.A. 1999c. Seven new species of mites (Acari: Acaridida) educed from different habitats in upper Egypt. Assiut J. of Agric. Sci., 30 (5): 65-80.

Eraky, S..A. 2000a. Identification key for some Acarididia mites (hypopi) (Acari:Astigmata) with descriptions of two new species. Assiut J. of Agric.Sci., 31: 341-371.

Eraky, S.A. 2000b. Four new species of genus Histiostoma kramer, 1876 (Acari: Astigmata) subsistent in manure and dunghills. Folia ent. hung., 61: 5-16.

Eraky, S.A. and Shoker, N.I. 1993a. Mites extracted from uprooted banana sucker (Acari: Anoetidae). Folia. ent. hung., 54: 51-56.
Eraky, S.A. and Shoker, N. I. 1993b. Description of two new anoetid mites (Acari: Anoetidae) collected from different habitats. Assiut J. of Agric. Sci., 24 (2): 233-241.

Eraky, S. A. and Shoker, N. I. 1994. Two new deutonymphs of the genus Histiostoma Kramer, 1876 (Acari : Histiostomatidae) existing in stored onions. Assiut J. Agric. Sci. 25 (2): 163-168.

Fain, A. 1967. Notes on two new heteromorphic deutonymphs (hypopi) (Acarina:Sarcoptiformes). Proc. Linn. Soc., New South Wales., 92 (3) : 246-250.

Fain, A. 1970. Un nouvel Anoetidae vivant dans la graisse de l'oreille d'un elephant (Acarina:Sarcoptiformes). Acta Zoo/. Path. Antverp. 50 : 173-177.

Fain, A. 1973. Notes sur les hypopes de Saproglyphidae. in. Le genre Carbovidia ZakhvalJ\&in, 1941. Bull. Ann. Soc. r. beige Ent. 109: 153-189.

Fain, A. 1974. Notes sur quelques hypopes d'Anoetidae (Acarina : Sarcoptiformes). Bull. Ann. Soc. r. Beige Ent., 110 : 58-68.

Fain, A. 1976. lies subantarctiques. 2- Families Acaridae, Anoetidae, Ereynetidae et Tarsonemidae (Astigmata, Prostigmata). Acarologia. 18: 302-328.

Fain, A. 1980a. Syringanoetus vandenberghi n.g, n. sp. (Acari, Astigmata). LiberAmicorum Walter van denBergh, Lannoo, Tielt, Amsterdam, : 115117.

Fain, A. 1980b. Hormosianoetus aeschlimanni n.g., n. sp. (Acari, Anoetidae) phoretique sur des Drosophiles d'elevage en Suisse. Rev. sui. Zool. 87 (3) : 753-756.

Fain, A. 1980c. A new genus of mite (Acari: Acaridae) phoretic on bees (Ctenocolletes) in Australia. Rev. West. Aust. Mus., 11 (2): 77-86.

Fain, A. 1984. Nouveaux hypopes de Myianoetinae provenant de crottes d'elephants au Rwanda (Acari, Anoetidae). Rev. Zoo., afr, 98 (2) : 279292.

Fain, A. 1987. Notes on the mites living in the flowers of Espletia spp. (Asteraceae) in Colombia. П :Espletiacarus andinus gen. n., spec. n. (Hemisarcoptidae) and Michaelopus inconus sp. n. (Acaridae). Entomol. Mitt. Zoo I. Mus. Hamburg 9: 37-47.

Fain, A. 1988. Observation on Congovidia Fain \& Elsen, 1971 and allied genera (Acari: Hemisarcoptidae). Bull. Ann. Soc. r. Beige Ent. 124: 125-130.

Griffiths, D.A. 1960. Some field habits of mites of stored products. Ann. Appl. Biol., 48: 134-144.

Griffiths, D.A. 1964. A revision of the genus Acarus (Acaridae, Acarina) Bull. Brit. Mus (nut. Hist.). 
(Zool.) 11 (6): 415-464.

Griffiths, D.A. 1966. Nutrition as a factor influencing hypopus formation in Acarus siro species complex (Acarina: Acaridae). J. Stored Prod. Res., 1 : 325-340.

Griffiths, D.A. 1977. A new family of astigmatid mites from lies Crozet, Sub-Antractia: Introducing a new concept relating to ontogenetic development of the idiosomal setae. J. Zool. (Lond.). 182:291-308.

Houck, M. A. and OC'onnor, B. M. 1991. Ecological and evolutionary significance of phoresy in the Astigmata. Ann. Rev. Entomol. 36: 611-636.

Hughes, A.M. 1961. The mites of stored food. Teck Bull. Minist. Agric. London. $\quad 9: 1-28$.

Hughes, A.M. 1976. The mites of stored food and houses. Tech. Bull. Minist. Agric. Fisheries and Food. 9 : 1-379.

Hughes, R.D. and Jackson, C.G. 1958. A review of the Anoetidae (Acari). Virginia J. Sci. 9. New Series, 1-198.

Kettle, D.S. 1995. Medical and veterinary entomology, $2^{\text {nd }}$ edition. C.A.B. International, Wallingford, Oxon, UK. 725 pp.

Mahunka, S. 1961a. Contributions to the Tyroglyphid fauna of Hungary (Acari). Ann. Univ. Scient. Budapest, Rolando Eotvos. 4: 113117.

Mahunka, S. 1961b. Neue und Wenig bekannte Milben-Arten aus Ungam. Folia. ent. hung., 14 : 437-446.

Mahunka, S. 1962a. Studien uber einheimische milben (Acaridae und Anoetidae). Acta Zool, hung., $8: 423-434$.

Mahunka, S. 1962b. Zwei neue Milbenarten aus Ungam (Acari, Anoetidae). Folia ent. hung., 15 : 517-522.

Mahunka, S. 1963a. Neue Anoetiden (Acari) aus Angola. Publ. Cult. Co. Diam. Ang. Lisboa. 63 : 25-44.

Mahunka, S. 1963b. Neue Anoetiden und Acariden (Acari) aus Angola. Publ. Cult. Co. Diam. Ang., Lisboa, 63: 49-66.

Mahunka, S. 1964. Ergebnisse der zoologischen forschungen von Dr. Kaszab in der Mongolie. Annls. Hist.Nat. Mus.Natn. Hung., 56 : 469-471.

Mahunka, S. 1967. The scientific results of the Hungarian soil. Zoological expedition to the Congo. Acta zool. hung., 13: 149-181.

Mahunka, S. 1968. Studies on the mite fauna of Hungary I. (Acari). Annls Hist. Nat. Mus. Natn. Hung., 60: 249-260.

Mahunka, S. 1969a. Xenanoetus vestigialis gen. n., and two new species of the genus Myianoetus Oudemans, 1913 (Acari: Anoetidae). Annls. Hist. Nat. Mus. Natn. Hung., 61: 359-362.
Mahunka, S. 1969b. The scientific results of the Hungary Zoology expendation, to Tanganyika, 14. Mites extracted from animal excrement and the nests of Tachyoryctes species. Annls. Hist. Nat. Mus. Natn. Hung., 61: 363-376.

Mahunka, S. 1972. Neue aufTenebrioniden (Coleoptera) gesammelte Anoetidenarten (Acarina) von den Salamon Inseln. Parasit. Hung., 5: 349-360.

Mahunka, S. 1973a. Auf Insekten Lebenden Milben (Acari:Acarida, Tarsonemida) aus Afrika. I. Acta Zool. Hung., 19: 75-123.

Mahunka, S. 1973b. Xenanoetus grandiceps sp. n., sowie weitere Angaben fiber die Anoetiden-fauna der Mongolei (Acari). Foliaent. hung., 26: 57-63.

Mahunka, S. 1973c. Auf Insekten Lebenden Milben (Acari:Acarida, Tarsonemida) aus Afrika, II. Acta Zool. Hung., 19: 289-337.

Mahunka, S. 1973d. Neue und Interessante Milben aus dem Genfer Museum V. Ceylanoetus excavatus gen. nov., sp. nov und andere neue Anoetida Arten aus Ceylan (Acari). Acarologia, 15: 506-513.

Mahunka, S. 1974a. Auflnsekten lebenden Milben (Acari:Acarida, Tarsonemidae) aus Afhka. III. Acta Zool, hung., 20: 367-402.

Mahunka, S. 1974b. Auflnsekten lebenden Milben (Acari:Acarida, Tarsonemida) aus Afrika. ni Acta Zool, hung., 20: 137-154.

Mahunka, S. 1975a. Auf Insekten Lebenden Milben (Acari:Acarida und Tarsonemida) aus Afrika. V. Acta Zool. Hung., 21: 39-72.

Mahunka, S. 1975b. Auf Insekten Lebenden Milben aus Australien und Neu-Guinea (Acari:Acarida, Tarsonemida). Annis Hist. Nat. Mus. Natn. Hung., 67: 317-325.

Mahunka, S. 1976. New and incompletely known Taxa from the families Acaridae and Anoetidae (Acari:Acarida). Acta Zool. hung., 22: 303-326.

Mahunka, S. 1977. Neue und interessante Milben aus dem Genfer Museum XIX. Eingie Angaben Zur Kenntnis der Milbenfauna der AmeisenNestem (Acari-Acarida, Tarsonemida). Arch. Sc. Geneve, 30: 91-106.

Mahunka, S. 1978a. The examination of myrmecophilous Acaroidea mites based on the investigations of Dr. C.W. Rettenmeyer (Acari: Acaroidea). I. Folia ent. hung., 31: 135-166.

Mahunka, S. 1978b. The scientific results of the Hungarian Zoological Expendations to tanganyika, 14-Mites extracted from animal excrement and the nests of Tachyoryctes species. Annls. Hist. Nat. Mus. Natn. Hung., 70: 363-376.

Mahunka, S. 1978c. Schizoglyphidae fam. n. and new taxa of Acaridae and Anoetidae (Acari: Acarida). Actazool. hung., 24: 107-131. 
Mahunka, S. 1979. The examination of myrmecophilous Acaroidea mites based on the investigation of Dr. C.W. Rettenmeyer (Acari: Acaroidea). n. Acta Zool. Hung, 25: 311-342.

Mahunka, S. 1981. Uber die Acariden und Anoetiden aus Tunesien (Acari) I. Folia ent. hung, 42: 135-137.

Mahunka, S. 1982a. Two new mites from the Juan Femandez Islands (Acai: Acarida and Oribatida). Folia ent. hung., 43 : 63-68.

Mahunka, S. 1982b. Neue und interessante Milben aus der Genfer Museum XXII. Uber zwei neue Milbenarten aus der Neogaea (Acari :Pygmephoridae, Anoetidae). Arch. Sc. Geneve, $35: 81-86$.

Mahunka, S. 1990. A survey of the superfamily Euphthiracaroidea Jacot, 1930 (Acari: Oribatida). Folia ent. Hung., 51: 37-80.

Mahunka, S. and Eraky, S. A. 1987. Mites extracted from manure and silo (Acari: Acaridae, Anoetidae and Tarsonemina), I. Folia ent. Hung., 48: $129-140$.

Mahunka, S. and Samsinak, K. 1973. Passaloglyphus kunsti sp. n. (Acari: Acaridae). Parasit. Hung., 6:261-265.

OC'onnor, B. M. 1982. Evolutionary ecology of astigmatid mites. Ann. Rev. Entomol. 27: 385409.

OC'onnor, B. M. 1984a. Phylogenetic relationships among higher taxa in the Acariformes, with particular reference to Astigmata. In Griffiths, D.A. and C.E. Bowman (eds.), Int. Congress Acarology VI, vol. 1. Ellis Horwood, Ltd., Chichester. :19-27.

OC'onnor, B.M. 1984b. Nomenclatural status of some family-group names in the non psoroptidid Astigmata (Acari: Acariformes), Internat.J Acarology, 10: 203-207.

OC'onnor, B.M. 1989. Systematic, ecology and host associations of Naiadacarus (Acari: Acaridae) in the great lakes region. The Great Lakes Entomologist, 22 (2): 79-94.

OC'onnor, B.M. 1990. Ecology and host associations of Histiogaster arborigms (Acan'.Acandae) in the great lakes region, particularly in the Huron Mountains of Northern Michigan. The Great Lakes Entomologist, 23 (4): 205-209.

OC'onnor, B.M. 1991. A preliminary report on the arthropod-associated Astigmatid mites (Acari: Acariformes) of the Huron Mountains of Huron Mountains of Northern Michigan, Academician
24: 307-320.

OC'onnor, B. M. 1993. Generic relationships in the Chaetodactylidae (Acari: Astigmata) with description of a new genus. Acarologia, 34 (4): 345-362.

OC'onnor, B.M. 1994. Life history modifications in Astigmatid mites (ed. Houck), Chapman \& Hall, New York, London, 6: 136-159.

OC'onnor, B.M. 1997. Two new mites (Acari: Acaridae) associated with long-tongued (Hymenoptera: Apidae) in North America. J. Kansas Entomol. Soc, 69: 15-34.

Samsinak, K. 1957. Acotyledon tetramorin. sp. eine neue myrmecophile Tyroglphidae (Acari). Acta Soc. Entomol. Cechosloveniae. 54: 396-399.

Samsinak, K. 1960. Ueber einige myrmekophile Milben aus der familie Acaridae. Acta Soc. Entomol. Cechosloveniae. 57: 185-192.

Samsinak, K. 1962a. Beitrage zur kenntnis der familie Anoetidae. Cas. Cs. Spol. entom., 59: 87-97.

Samsinak, K. 1962. Neue entomophile Acari aus China. Cas. Cs. Spol. entom., 59 : 186-206.

Samsinak, K. 1966. Zwei interessate auf Insekten Lebende hypopi (Acari : Acaridoidea). Zool. Anz., 176:124-127.

Samsinak, K. 1972. Die auf Formica lemani Bondr. (Hymenoptera) lebenden hypopi der Gatting Anoetus Dujardin, 1842 (Acari). Abh. Ber. Nat. Gorlitz, 45 (13) : 33-36.

Scheucher, R. 1957. Systematik und Okologie der deutscher Anoetina, In Betrage Zur Systematik und Okologie mitteleuropdische Acarina. (ed. Stammer, H.J.). I: 233-284.

Turk, E. and Turk, F. 1959. Systematik und Okologie der Tyroglyphiden Mitteleuropas. In Betrage Zur Systematik und Okologie Mitteleuropdische Acarina (ed. Stammer, H.J.). I: 3-231.

Woodring, J.P. 1963. New species of Histiostoma and Histiogaster with observations on their biology. Proc. La. Acad. Sci., 26 : 49-57.

Woodring, J.P. 1969. Observations on the biology of six species of acarid mites. Ann. Ent. Soc.Amer., 62 (1) : 102-108.

Woodring, J.P. 1973. Four new anoetid mites associated with halictid bees (Acarina: Anoetidae, Hymenoptera: Halictidae). J. Kansas Ent., 46 (3): 310-327.

Zakhvatkin, A.A. 1941. AGBS translation of: Fauna of U.S. S.R. Arachnoidea. 6(1): Tyroglyphoidea. 